\title{
Is there a correlation between the size of the BCG scar and renal scar of urinary tract infections in children?
}

\author{
Çocuklarda idrar yolu enfeksiyonu sonrası gelişen renal skar ile BCG skarı boyutu arasında bir \\ ilişki var mıdır?
}

\author{
Salih Kavukçu ${ }^{1}$, Demet Alaygut ${ }^{1}$, Belde Kasap ${ }^{1}$, Alper Soylu ${ }^{1}$, Gamze Çapakaya ${ }^{2}$, Mehmet Türkmen ${ }^{1}$
}

\begin{abstract}
Objective: Pyelonephritis cause cellular death, and development of scars in kidneys. The aim of this study is to demonstrate a correlation (if any) between renal scar, and size of the scar induced by BCG vaccine in children who had experienced urinary tract infections. In case of detection of any correlation, BCG scar formation can be used as a determinative marker of renal scars, which develop following urinary tract infection.
\end{abstract}

Methods: Patients with a history of urinary tract infection at least 4 months old who had undergone ${ }^{99 m}$ TcDMSA scanning were included in this study. Vertical and horizontal diameters of BCG scars of the patients in the study group were measured. For statistical analysis the greatest diameter was taken into consideration, and the patients were divided into 2 subgroups based on the greatest diameter of their BCG scars (Subgroups 1, $\leq 5 \mathrm{~mm}$, and 2, $>5 \mathrm{~mm}$ ). The patients were also evaluated in 2 groups as those with (Group 1) or without (Group 2) scars. Both groups were compared with subgroups with the largest scar diameters of $\leq 5 \mathrm{~mm}$ or $>5 \mathrm{~mm}$

Results: Study population included 108 (82 girls) patients. DMSA detected scars in a total of 51 patients. Mean ages of the patients with and without scars were not different $(p=0.414)$. No significant difference was found in size of the BCG scars between renal scar positive and negative groups ( $p>0.05)$.

Conclusion: No correlation was found between development of renal scar and the size of BCG scar in children after urinary tract infection. J Clin Exp Invest 2013; 4 (1): 8-12

Key words: BCG scar, renal scar, urinary tract infection, children

\section{ÖZET}

Amaç: Pyelonefrit böbreklerde hücre ölümü ve skar gelişimine neden olmaktadır. Bu çalışmanın amacı, idrar yolu enfeksiyonu geçiren çocuklarda oluşan renal skar ile BCG skar boyutu arasında herhangi bir korelasyon olup olmadığını göstermektir. Bir korelasyon bulunması durumunda BCG skarı idrar yolu enfeksiyonu sonrası gelişen renal skarda belirleyici bir marker olarak kullanılabilecektir.

Yöntemler: En az 4 ay önce idrar yolu enfeksiyonu geçirmiş, ${ }^{99 m}$ TcDMSA sintigrafisi çekilmiş olan çocuk hastalar bu çalışmaya alındı Çalışma grubundaki hastaların BCG skarı vertikal ve horizontal çapta ölçüldü. İstatistiksel analiz için en büyük çap dikkate alındı ve $\leq 5 \mathrm{~mm}$ ve $>5 \mathrm{~mm}$ olarak iki gruba ayrıldı. Hastalar renal skarı olanlar (Grup 1) ve renal skar geliştirmeyenler (Grup 2) olmak üzere iki grupta toplandı. Her iki grup, BCG skar boyutu $\leq 5 \mathrm{~mm}$ veya $>5 \mathrm{~mm}$ olan gruplar ile karşılaştırıldı.

Bulgular: 108 (82 kız) hasta çalışmaya dahil edildi. DMSA'da skar olan toplam 51 hasta vardı. Skarı olan ve olmayan hastaların ortalama yaşları farklı değildi. $(p=0,414)$ Renal skar bulunan ve bulunmayan gruplar arasında BCG skar boyutu bakımından istatistiksel olarak anlamlı bir fark bulunmadı $(p>0,05)$.

Tartışma: İdrar yolu enfeksiyonu geçiren çocuklarda renal skar gelişimi ile BCG skar boyutu arasında bir korelasyon bulunmadı.

Anahtar kelimeler: BCG skarı, renal skar, idrar yolu enfeksiyonu, çocuklar

${ }^{1}$ Dokuz Eylül University, Faculty of Medicine, Department of Pediatrics, Divison of Nephrology, Izmir, Turkey

${ }^{2}$ Dokuz Eylül University, Faculty of Medicine, and Department of Nuclear Medicine, Izmir, Turkey

Correspondence: Demet Alaygut,

Dokuz Eylül University Faculty of Medicine Department of Pediatrics, İzmir, Turkey Email: demetalaygut@yahoo.com

Received: 21.11.2012, Accepted: 21.02.2013

Copyright (C) JCEI / Journal of Clinical and Experimental Investigations 2013, All rights reserved 


\section{INTRODUCTION}

Pyelonephritis can cause programmed cell death, and scar development in kidneys. Apoptotic cells secrete profibrogenic, and inflammatory cytokines such as transforming growth factor beta (TGF- $\beta$ ), and tumor necrosis factor alfa (TNF- $\alpha$ ) leading to the development of renal parenchymal damage, and scar formation. ${ }^{1}$ It is possible to detect renal cortical scar using ${ }^{99 \mathrm{~m} T c D M S A}$ scanning. ${ }^{2}$ Bacille Calmette-Guerin (BCG) has been used extensively as a vaccine against human tuberculosis for over 70 years. In addition to its role as a vaccine against tuberculosis, BCG vaccine has also been used as an immunotherapeutic agent by intravesical instillation in superficial cancer of the bladder. ${ }^{3,4}$ Pediatric tuberculosis (TB) should be accepted as a publichealth emergency, because young children have a much higher risk of developing severe and fatal disease than adult cases. The Turkish Ministry of Health started a routine national immunization program in order to prevent TB since 1953. In 1990's two doses of BCG were administered in children, the first within 2 months of birth and the second at the age of 7 years, and in 2006, a single dose is started to be administered at 2 months of age. ${ }^{5}$ Following vaccination, a local scar develops on the injection site via cellular immunity. ${ }^{6}$ Predominantly interferon gamma (IFN- $\mathrm{Y}$ ), and other cytokines such as TNF- $\alpha$ and IL-2 type 1 are secreted by both CD4+ and CD8+ T cells which involve in the development of scars. ${ }^{7}$

The aim of this study is to reveal a correlation (if any) between renal scar development after urinary tract infection and the size of the BCG scar. Therefore, in case of a correlation, presence, and size of a BCG can be used as an important determinative marker for the development of renal scar.

\section{METHODS}

Medical files of children between the ages 0-18 who undergone upper urinary tract infection (acute pyelonephritis) and were followed-up in Dokuz Eylül University Faculty of Medicine, Department of Pediatric Nephrology were retrospectively examined. Local ethics committee approval was obtained for the study. Patients were selected due to their past medical records, and the following parameters were considered for the acute pyelonephritis diagnosis at least 4 months ago: presence of high fever, positive indirect tests of inflammation [elevated peripheral white blood cell (WBC) count, elevated C-reactive protein (CRP)]. Another selection criteria for the study patients was whether they had undergone ${ }^{99 m}$ TcDMSA scanning. Number of pyelonephritis and the etiologic factors were ignored. BCG scars number and BCG scar measurement were detected. All patients had at least one, and many had 2 BCG scars. Both vertical and horizontal diameters of the BCG scars were measured by the same person. Exclusion criteria were suspicious or lower tract urinary infections and lack of scintigraphic examination of patients. Following parameters were recorded: age, gender, the presence of renal scar with ${ }^{99 m}$ TcDMSA scanning, the presence and number of BCG scars; both vertical and horizontal diameters of the BCG scar as millimeters. For statistical analysis, the greatest diameter was taken into consideration, and the patients were divided into 2 subgroups based on the greatest diameter of their BCG scars (Groups 1, $\leq 5 \mathrm{~mm}$, and 2, >5 mm). The patients were also evaluated in 2 groups as those with (Group 1) or without (Group 2) scars.

Data were analyzed with Chi-square test, Mann- Whitney $U$ test and correlation tests (Pearson and Spearman) to detect the differences or relationships between the parameters using SPSS (version 15.0) software program. Statistical significance was specified as $p<0.05$.

\section{RESULTS}

Study population included 108 (82 girls, $75.9 \%$ ) patients. Mean age of the patients were $87 \pm 58$ (6216) months. DMSA scanning detected scars in 51 $(47.2 \%)$ patients. 75 patient $(69.4 \%)$ had one BCG scar. Mean ages of the patients with and without scars were not different $(p=0.414)$. No statistically significant intergroup differences were found in size of BCG scars between renal scar positive and negative groups (Table 1 ).

Because, girls constituted most of the patient population, intragroup comparative evaluations of male and female cases was not performed (Table $2,3)$

In all patient groups, correlation analysis was used to find relationships between variables. As a result, age was found to significantly positively correlated with horizontal diameter of BCG scar $(r=$ $0.525, p<0.001)$, vertical diameter of BCG scar $(r$ $=0.05, p<0.001)$ and numbers of BCG scars $(r=$ $0.492, p<0.001)$. These results are shown in Table 4. 
Table 1. General characteristics of the patients with and without scars

\begin{tabular}{lccc}
\hline & $\begin{array}{c}\text { DMSA }^{*} \\
\text { Scar }(+)\end{array}$ & $\begin{array}{c}\text { DMSA }^{*} \\
\text { Scar }(-)\end{array}$ & $p$ \\
\hline Age (months) & $84.2 \pm 60.3$ & $75.1 \pm 56.5$ & 0.414 \\
Sex (female/male) & $33 / 18$ & $49 / 8$ & 0.010 \\
BCG scar size $(\mathrm{mm})^{* *}$ & $4.6 \pm 2.6$ & $5.1 \pm 2.3$ & 0.357 \\
BCG scar size & $33 / 13$ & $31 / 16$ & 0.834 \\
$\leq 5 \mathrm{~mm}^{* *} />5 \mathrm{~mm}^{* *}(\mathrm{n})$ & & & \\
\hline
\end{tabular}

* Pyelonephritic scar as detected by ${ }^{99 m}$ TcDMSA scanning, ** As measured from the longest diameter of the scar

Table 2. Renal scar positivity, and its correlation with BCG scars in male patients

\begin{tabular}{lccc}
\hline Male & $\begin{array}{c}\text { DMSA } \\
\text { Scar }(+)^{*}\end{array}$ & $\begin{array}{c}\text { DMSA } \\
\text { Scar }(-)\end{array}$ & $p$ \\
\hline BCG Scar size $(\mathrm{mm})^{* *}$ & $4.5 \pm 2.6$ & $3.8 \pm 1.6$ & 0.546 \\
BCG scar size & $11 / 6$ & $6 / 1$ & 0.625 \\
$\leq 5 \mathrm{~mm}^{* *} />5 \mathrm{~mm}^{* *}(\mathrm{n})$ & & & \\
\hline
\end{tabular}

*Pyelonephritic scar as detected by ${ }^{99 m}$ TcDMSA scanning

${ }^{* *}$ As measured from the longest diameter of the scar

Table 3: Renal scar positivity, and its correlation with BCG scars in female patients

\begin{tabular}{lccc}
\hline Female & DMSA & DMSA & p \\
& Scar $(+)^{*}$ & Scar $(-)$ & \\
\hline BCG Scar size $(\mathrm{mm})^{* *}$ & $4.7 \pm 2.5$ & $5.3 \pm 2.3$ & 0.305 \\
BCG Scar $<=5 />5(\mathrm{n})$ & $22 / 7$ & $22 / 15$ & 0.489 \\
\hline
\end{tabular}

*Pyelonephritic scar as detected by ${ }^{99 m}$ TcDMSA scanning

${ }^{* *}$ As measured from the longest diameter of the scar

Table 4. Correlation between age, horizontal and vertical diameter and number of BCG scars

\begin{tabular}{lcc}
\hline Parameters & \multicolumn{2}{c}{ Age } \\
\cline { 2 - 3 } & r value & $p$ value \\
\hline Horizontal diameter of BCG & 0,525 & $<0.001$ \\
Vertical diameter of BCG & 0,500 & $<0.001$ \\
Numbers of BCG & 0,492 & $<0.001$ \\
\hline
\end{tabular}

\section{DISCUSSION}

Scar is defined as proliferation of avascular connective tissue rich in collagen fibers developed following cutaneous and visceral organ inflammation. ${ }^{8}$ Scars develop because of some complex interactions between cells, and cytokines. Especially,
CD4 + T cells, and TGF $\beta$ producing T cells play important roles. As a profibrogenic mediator, the expressions of TGF $\beta$ increases mostly in all organs affected by the development of fibrosis. TGF $\beta$ released by many cell types including epithelial cells, macrophages, and myofibroblasts. Secreted TGF $\beta$ is inactive, and it undergoes proteolysis and conformational changes by the action of integrin, and thromboposdin. ${ }^{9}$ TGF $\beta$ regulates cell proliferation, differentiation, apoptosis, and immune responses involved in extracellular matrix turnover. These two basic cell types and mediators involve in both development of dermal scar after BCG vaccination, and scar occurrence after renal inflammation.

BCG vaccine is a Mycobacterium bovis strain, which is transformed into a nonvirulent form carrying structural characteristics of the tuberculosis bacilli. It protects us from tuberculosis, and infections caused by other atypical mycobacterial strains. ${ }^{10}$ BCG vaccine activates T lymphocytes, and macrophages to develop an immune response. ${ }^{11}$ Within 3-6 weeks, an ulcerated papillary lesion develops on this region, and a scar as a result of cell-mediated immune response..$^{10}$ Studies investigating newborns after vaccinations, performed within the first months of life, have demonstrated scar formation within the first 6 postnatal months. ${ }^{12}$ The authors reported that scars do not form when immune system of the infants is not fully mature, and in cases of vaccination performed using an improper technique or an impotent vaccine. ${ }^{13}$ At least one BCG scar was present in our entire patient group, and none of our patients was immunosuppressed. A positive correlation was found between age and horizontal and vertical diameter of BCG scars in this study. This situation can be explained by maturation of the immune system with increasing age. At the same time age was correlated significantly with the number of BCG scars. The reason for this can be done only single dose vaccine at 2 months of age after the year 2006. Therefore, older children had more of one vaccine.

A local inflammatory response is elicited when attenuated live tuberculosis vaccine is injected intradermally. As epidermal macrophages, dendritic cells present this antigen to CD4+T cells with resultant release of IFN- $\gamma$ which activates macrophages. While macrophages release cytokines, they trigger inflammation, and induce fibrosis. CD4+ T cells effect vascular endothelium and induce expression of adhesion molecules, and secretion of cytokine like TNF, which increases production of chemokines. Response to cytokines produced by CD4+ T cells manifests itself with storage of fibrins. ${ }^{14}$ Similarly, 
T cells involve in the induction of fibrotic reaction in acute, and chronic destructive processes in kidneys, and in immune complex-mediated glomerulopathies. Three mechanisms of these processes have been demonstrated in various studies. Firstly, T cells directly affect TGF $\beta$, and renal fibroblasts with resultant migration, proliferation, and also differentiation of renal fibroblasts into myofibroblasts. They effect macrophage population in the affected site, and induce transformation of some profibrotic cytokines (platelet-derived growth factor (PDGF), TGF $\beta 1$, and CTGF) and fibroblastlas into myofibroblasts. Thirdly, they directly affect tubular epithelial cells together with growth factors, and cytokines in order to stimulate fibroblasts..$^{15}$ Myofibroblasts are cellular mediators of fibrosis. Normally, myofibroblasts do not exist in tubulointerstitial region. Following tissue damage, together with macrophages, myofibroblasts originating from mesenchymal cells start to accumulate within tissues in response to TGF $\beta$, PDGF and connective tissue growth factor (CTGF) factors and alike. Besides, they play a role in many types of leucocytes, and formation of fibrosis in the parenchymal tissue. ${ }^{16}$

Urinary tract infection is an important cause of infection in that they lead to the formation of scar tissue, secondary hypertension, and chronic kidney damage in children. As an outcome of infections, tubular epithelial dysfunction develops, fibrogenic cytokines are released, and inflammatory cells migrate into kidneys. ${ }^{17,18}$

As is the case with all parenchymal organs, TGF $\beta 1$ is the most important cytokine in the development of fibrosis. Another important immunological pathway in both dermal and renal fibrosis involves toll-like receptors (TLRs) on fibroblasts and their ligands. TLRs are functionary components of the innate immune system. Fibroblasts in various tissues are known to express TLRs. Especially, the importance of increased TLR4 expression and its inducive function in the release of pro-inflammatory cytokines is already acknowledged. ${ }^{19}$

In the absence of TLR4, or in case of a genetic defect, production of antimicrobial peptides, and accumulation rate of neutrophils decrease. When compared with normal skin, increased TLR4 expression was observed in dermal atrophic scars. ${ }^{19}$

In this study, assuming similar development mechanisms for all scar types, we aimed to investigate the correlation between size of a BCG scar, and development of renal scar. If any correlation is established, then presence and size of a BCG scar can be used as a determinative marker in the development of renal scar. However, any correlation between the size of a BCG scar, and the presence of renal scar was not found.

In the development of renal scar secondary to acute pyelonephritis, immune state of the patient, especially his/her innate immunity is an important determinative factor. Besides, some polymorphisms involving in the development of scar formation have been described. Egyptian pediatric patients with pyelonephritis were compared with healthy controls, and two TGF $\beta$ 1, and two vascular endothelial growth factor (VEGF) variants were identified. ${ }^{20}$ Similarly, in Irish children TGF $\beta 1$, and VEGF variants were detected. ${ }^{21}$ Another limitation of our study, just as is the case with cytokine polymorphisms, we did not know TLR4 levels in groups with or without development of renal scar. In our patient group, presence of any polymorphism is not known. This phenomenon might affect the results of our study.

In conclusion, development of a scar is a process resulting from complex interactions between cells and cytokine release. For the mechanism of scar formation, which is thought to result from similar cellular mechanisms and mutual cytokine release, to be able to delineate the association between formation of BCG scar and renal scar? Further large-scale investigations with greater number of populations are needed.

\section{REFERENCES}

1. Kisseleva T, Brenner DA. Fibrogenesis of parenchymal organs. Proc Am Thorac Soc 2008;5:338-342.

2. Rossleigh MA. QJ Scintigraphic imaging of renal infections. Nucl Med Mol Imaging 2009;53:72-77.

3. Krege S, Giani G, Mayer R, et al. A randomized multicenter trial of adjuvant therapy in superficial bladder cancer: Transuterhral resection plus bacillus Calmette Guerin J Urol 1996;156: 962-966.

4. Grange JM. Complications of bacille Calmette Guerin (BCG) vaccination and immunotherapy and their managemnet. Commun Dis Publ Health 1998;1:84-88.

5. Hocaoğlu AB, Erge DO, Anal O, et al. Characteristics of children with positive tuberculin skin test. Tuberk Toraks 2011;59:158-163.

6. Rani SH, Vijayalakshmi V, Sunil K, et al. Cell mediated immunity in children with scar-failure following BCG vaccination. Indian Pediatr 1998;35:123-127.

7. Soares AP, Scriba TJ, Joseph S, et al. Bacillus Calmette-Guerin vaccination of Human T Cells with Complex Newborns induces cytokine and Phenotypic Profiles. J Immunology 2008;1805:3569-3577.

8. Madeleine A. Vernon, Mylonas KJ, Hughes J. Macrophages and Renal Fibrosis. Semin Nephrol 2010;30:302-317.

9. Hugo C, Daniel C. Thrombospondin in renal disease. Nephron Exp Nephrol 2009;11:61-66. 
10. Tosa M, Murakami M, Ghazizadeh M, et al. Chronologic change of the maximum dimension of Bacillus Calmette-Guerin-induced keloids. Dermatol Surg 2009;35:189-194.

11. Fine PE. Bacille Celmette- Guerin vaccines: a rough guide. Clin Infect Dis 1995;20:11-14.

12. Floyd S, Ponnighaus JM, Bliss L, et al. BCG scars in northern Malawi: sensitivity and repeatability of scar reading, and factors affecting scar size. Int $\mathrm{J}$ Tuberc Lung Dis 2000;4:1133-1142.

13. Santiago EM, Lawson E, Gillenwater K. A Prospective study of Bacillus Calmette-Guérin scar formation and tuberculin skin test reactivity in infants in Lima. Peru Pediatrics 2003;112:298-301.

14. Camcıoğlu Y, Deniz G (2007) Temel İmmunoloji İstanbul: Medikal yayıncılık pp 83-103.

15. Nikolic-Paterson DJ. CD4+ T cells: a potential player in renal fibrosis. Kidney Int 2010;78:333-335.

16. Vernon MA, Mylonas KJ, Hughes J. Macrophages and renal fibrosis. Semin Nephrol 2010;30:302-317.
17. Neilson EG. Mechanism of disease: Fibroblasts- a new look at an old problem. Nat Clin Pract Nephrol 2006;2:101-108.

18. Ruiz-Ortega M, Puperez M, Esteban V, et al. Angiotensin II: a key factor in the inflammatory and fibrotic responce in kidney diseases. Nephrol Dial Transplant 2006;21:16-20.

19. Wang J, Hori K, Ding J, et al. Toll-like receptors expressed by dermal fibroblasts contribute to hypertrophic scarring. J Cell Physiol 2011; 226:1265-1273.

20. Hussein A, Askar E, Elsaeid M, et al. Functional polymorphisms in transforming growth factor- beta1 (TGFbeta-1) and vascular endothelial growth factor (VEGF) genes modify risk of renal parenchymal scarring following childhood urinary tract infection. Nephrol Dial Transplant 2010;25:779-785.

21. Kuroda S, Solari V, Puri P. Association of transforming growth factor- beta 1 gene polymorphism with familial vesicoureteral reflux. J Urol 2007;178:1650-1653. 